Ethiopian Journal of Environmental Studies \& Management 7(5): 478 - 487, 2014

ISSN:1998-0507

doi: http://dx.doi.org/10.4314/ejesm.v7i5.2

Submitted: March 13, 2014

Accepted: August 01, 2014

\title{
ASSESSING ENVIRONMENTAL IMPACTS OF INLAND SAND MINING IN PARTS OF OGUN STATE, NIGERIA
}

\author{
${ }^{*}$ ADEDEJI, 0.H., ${ }^{1}$ ADEBAYO, H.O. ${ }^{2}$ AND SOTAYO, E.I. ${ }^{1}$ \\ ${ }^{1}$ Department of Environmental Management and Toxicology, Federal University of Agriculture, \\ PMB 2240 Abeokuta, Nigeria \\ ${ }^{2}$ Department of Geography and Regional Planning, Olabisi Onabanjo University, \\ PMB 2002, Ago-Iwoye, Nigeria
}

\begin{abstract}
Sand is a valuable resource for construction and other purposes, however sand mining often result in serious environmental problems such as land degradation, loss of agricultural lands and biodiversity, as well increased poverty among people. This study assessed the environmental impacts of inland sand mining in six selected local government areas of Ogun state, Nigeria. Twenty-seven (27) inland sand mining sites were identified, fourteen (14) of which are currently active mining sites while thirteen (13) are abandoned. The geographic location and attributes sites were captured for a spatial analysis using Geographic Information System (GIS). The sites were mapped and classified based on the severity of the damage to the ecological system. The study revealed that three of the local governments areas i.e. Abeokuta South, Ifo, Obafemi/Owode and Ado-Odo/Ota have inland sand mining sites with severe degradation, while Sagamu and Ewekoro local governments areas have inland sand mining sites that can be regarded as moderately and less degraded respectively. The intensive urban and industrial developments around these areas contributed enormously to the increased demand of sand for building and construction. Natural resources particularly, land, water quality and quantity, air quality, are the most significant impacts. Other impacts include loss of farmland, depreciation of land value, and destruction of infrastructural facilities. The study concluded that sand mining should be subject to planning and other controls in order to curtail its negative impacts.
\end{abstract}

Keywords: Urbanization, Housing, GIS, Land degradation, Sand mining, Pollution

\section{Introduction}

Sand is a valuable resource and a main input in the construction industry in many parts of the world (Erskine and Green, 2000; Gob et al., 2005). Sand mining is the removal of sand from their natural configuration. Mining of sand occurs both on small and large-scale in major parts of the country. With an estimated 16 million housing deficit (Ezekiel, 2010; Isah, 2011) and infrastructural development in Nigeria, there will continue to be the great demand for sand and other construction materials (Omole and Ajakaiye, (1998). Ogun State has experienced rapid population growth and physical expansion especially since the mid 1980s due to the influx of people from different parts of the country. These in turn have exerted pressure on the needs for housing provision, in addition to the already existing demand for civil works such as construction and repair of bitumen roads, bridges, buildings by public works and house repair and construction by individuals

*Corresponding Author: Adedeji, O.H.

Email: hakeemdare1222@yahoo.co.uk 
(Hemalatha et al., 2005). The increasing rate of urbanization across the globe has brought with it several challenges ranging from physical, economic, social, to environmental among other issues (Cohen, 2006; Chelala, 2010; Kadi et al., 2012). To cater for the rapid urbanization, several sites are now being exploited for the mining of sand and other building materials. Traditionally, sites for sand mining are rivers and beaches; however, sand is mined from river mouths, banks and even at inland sand deposits. Many inland sand deposits, which are lateritic in nature, are under immense pressure due to various kinds of human activities among which indiscriminate extraction of sand is the most disastrous (Kondolf, 1994; Sayami and Tamrakar, 2007). Typically inland sand mining operations begins with the removal of overburden from the top of the sand formation using scrapers or tracked excavators and off-road haul trucks. The overburden is often hauled to the perimeter of the mine site and piled into berms. Once the overburden has been removed, the sand is excavated. Depending upon the geological formation, blasting may be used to make the sand containing material more amenable to excavation. Large tracked excavators or rubber-tired front-end loaders typically perform excavation. In most of the inland sand mining sites in Ogun state, the excavated sand materials are loaded on trucks by hired labourers using shovels.

Rapid urbanization is a major cause for sand demand and is responsible for unsustainable extraction of sand from the many illegal inland sand mining pits found in many parts of the country. The interaction between sand mining operators, citizenneighbours, and government becomes more confrontational as result of more sand excavation sites located in urban and residential areas. Conflicts have centered on environmental and social issues such as noise, truck traffic, dust, stream-water quality, reclamation, biodegradation, pollution and visually unpleasant landscapes (Willis and Garrod, 1999), and the citizens concern on the adequacy of regulatory efforts of the government to control these negative effects. Environmental impacts of mining are well documented and the literature abound with environmental impacts in the form of waste management, impacts to biodiversity and habitat, deforestation of land with the consequent elimination of the vegetation, pollution (water, air, land and even noise pollution) etc. (Willis and Garrod, 1999; Abdus-Saleque, 2008). In Ghana and many other tropical areas of mining, it is noted that mining is a major cause of deforestation and forest degradation, generating a large number environmental impacts (World Rainforest Movement, 2004). It is noted that large-scale mining activities generally continue to reduce the vegetation of most of the mining communities to levels that are destructive to biological diversity (Akabzaa, 2000; Akabzaa and Darimani, 2001). Davis and Tilton (2005) also suggest that local communities tend to bear the negative impacts of mining be they social, economical or environmental. It is therefore important to make effort to stem these problems through informed decision-making. However, making informed decision in many areas including monitoring sand mining activities often involves complicated processes. For optimal decisionmaking, information from various sources is required such as spatial information, which is essential to address activities of sand mining and their impacts on the environment (Burrough and McDonnell, 2002).

Geographic information systems (GIS) can play major role in the management of mapped or spatial data prior to, during, and after sand mining activities (Chindo, 2011). It can provide maps of sand mining sites showing the level of degradation and help or serve as a decision support capability (Heywood et al., 2006; Chandra and Ghosh, 
2009). Geographic information systems (GIS) are one of the most popular tools utilized in decision making concerning resource utilization. It has had a profound effect on decision support system development, especially environmental modelling and model development, because it can supply functionality for dealing with spatial information that is required in most decision-making processes. GIS make mapped information available to decisionmakers and field personnel in real time. Although, site requirements for sand mining activities vary, as do their site-specific impacts on the environment, however, with GIS, we can make significant effort in the analysis or screening of potential sites by considering the requirements of sand mining and identifying and mapping locations within a region that meet these criteria. It is important to identify the sand mining areas and find how to monitor and control the activities so that environmental degradation can be slowed down.

The main objective of the study was to map inland sand mining sites and their environmental impacts parts in Ogun State, Nigeria. The specific objectives are to: 1) identify the mining sites in Ogun State, 2) capture both geometric and attribute data of these locations, and, 3) examine the environmental impacts of the sand mining activities.

\section{Materials and methods}

To determine the extent of illegal inland sand mining and their impacts requires not only information about the quantity and types of mineral activities, but also information about the geographical location where the activity occurs. For example, the geographical locations of the different sand mining sites can be documented at a range of spatial scales whether to cover a wider area (often 100s to 1000s of square kilometres) or to a small-scale license that may relate to less than a hectare of land. Geographic Information System (GIS) combines this variety of scales and creates relationships to determine the spatial pattern of sand mining activities. The GIS model aims to depict the distribution of inland sand mining sites in the study area and this integration of a variety of GIS datasets and multiple iterations of expert review and interpretation (Schleupner and Schneider, 2012). This study employed the use of GIS process or task consisting of: input, manipulation, management, query and analysis, and visualization (ESRI, 2010). For these purposes, the GIS tool ArcGIS 9.3 and Goggle Earth maps were used in the study. These tasks have been summarized into three major components: database construction, analysis and results. The methodology covers various stages, beginning with a thorough digitization of Ogun State map collected from the Bureau of Lands and Survey in Abeokuta, Ogun State (Figure 1). Then visitations were made to the inland sand mining sites for geographic and attribute data capturing. The final stage was collation of these data in a database and relating the database with the digitized map of Ogun State. Geographic coordinates of the sites and other details within the six local governments were obtained using of Global Positioning System (GPS) handheld instrument (Garmin 76) and recorded in the GPS as waypoints.

Data collection for the study covered a period of seven weeks that initially began from September 24 to November 12 2012. In total twenty-seven sites were visited and analysed within six local governments in Ogun State (Figure 2). Documentation of inland sand mining sites in the study area using local knowledge and Goggle Earth maps were made. In addition to the GIS analysis, this study identified target groups including individual landowners, residents of the area, groups of farmers whose farms were located close to mining sites, and sand 
mining operators (miners and sellers). Government officials from relevant departments and agencies responsible for sand and other mineral mining and other land use management systems were also included.
The aim of the selection was particularly to give broad views on the subject (Huntington, 2000). The questionnaire focused on respondents' views of the impacts of sand mining.

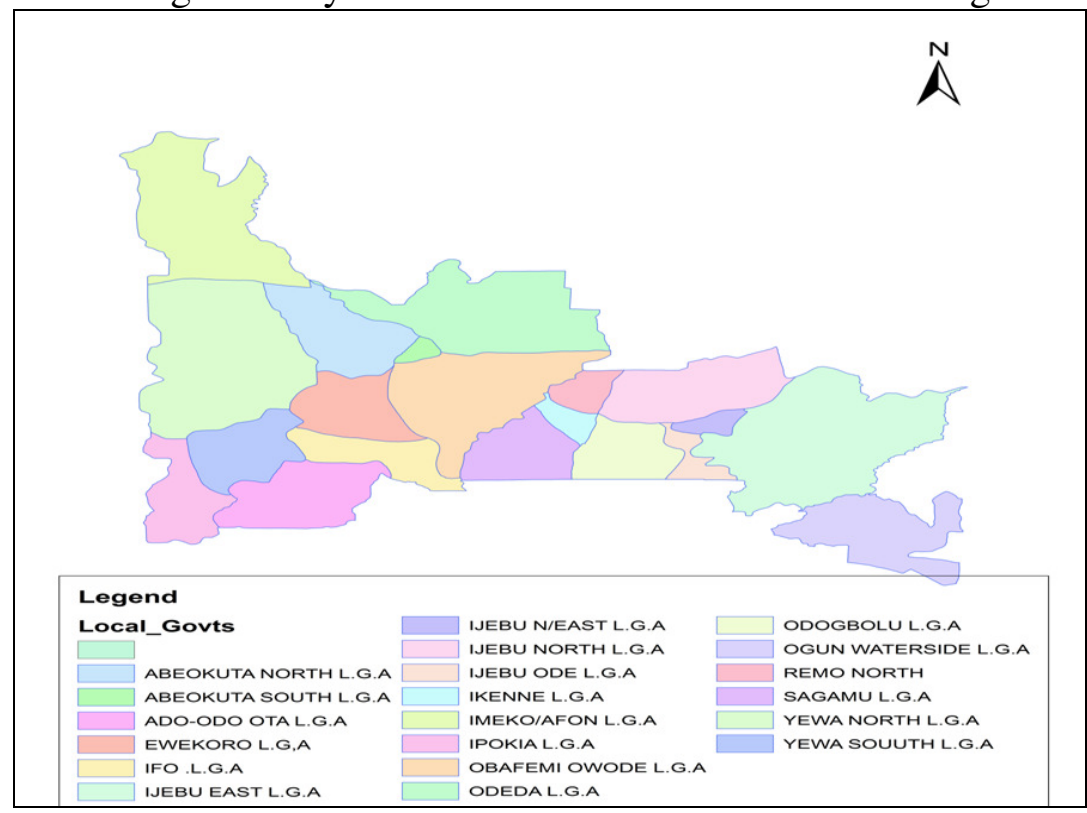

Figure 1: Map of Ogun State show the 20 Local Government Areas

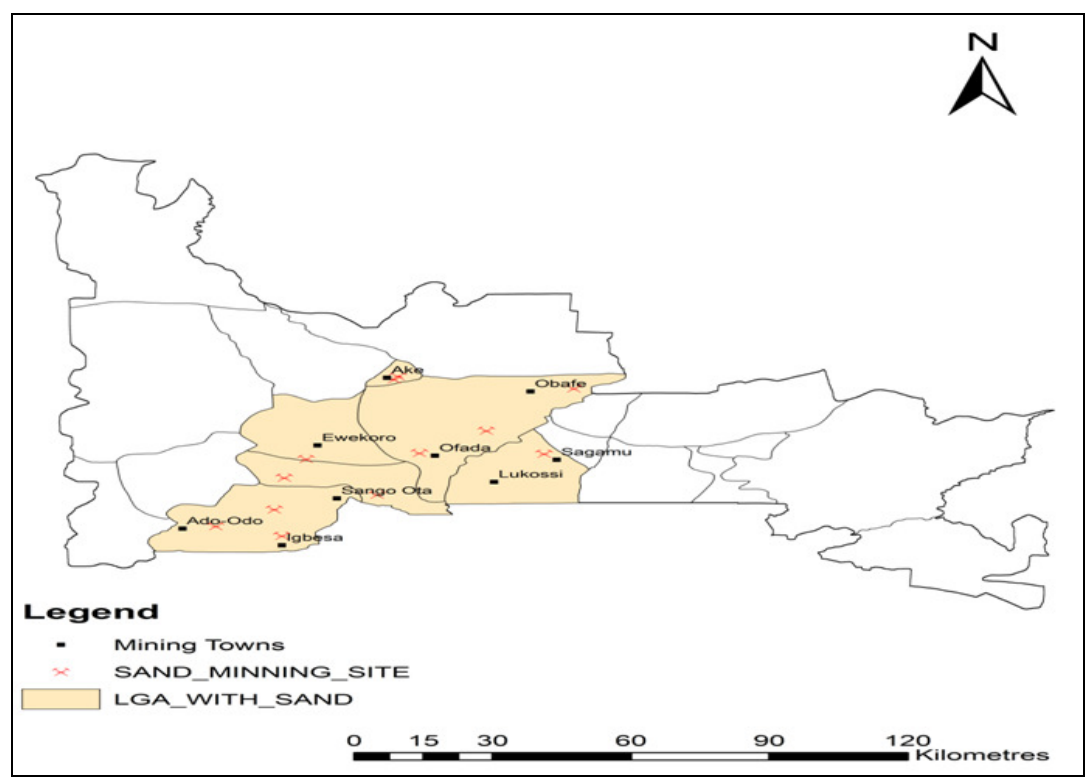

Figure 2: Selected Sand Mining LGA in Ogun State

\section{Results and Discussion}

Twenty-seven (27) inland sand mining sites were identified in the study area, 14 of these are currently active mining sites with excavation ongoing. Ten (10) are presently not in use, while three (3) are abandoned and now used as open dumpsites. The survey covered the operators of the fifteen (15) active mining sites as other operators at the 
others sites were not present when visitations were made (Table 1).

\section{Environmental Impact of Sand Mining Ogun State}

Figure 3 shows the mining sites in the six selected local government areas with the level of degradation. The GIS analysis showed that three of the local governments areas i.e. Abeokuta South, Ifo, Obafemi/Owode and Ado-Odo/Ota have inland sand mining sites with severe degradation, while Sagamu and Ewekoro local governments areas have inland sand mining sites that can be regarded as moderately and less degraded.

Sand mining is essentially a destructive development activity where ecology suffers at the altar of economy with huge environmental costs (Jiriko, 1995; Makweba and Ndonde, 1996).

Table 1: Attribute Table showing some of the sample locations

\begin{tabular}{lllll}
\hline OBJECTID & SHAPE* & X_COORDINATE & Y_COORDINATE & TOWN_NAME \\
\hline 1 & Point & 501571.03 & 801576.06 & Aiyetoro \\
2 & Point & 495932.13 & 781543.31 & Ibeshe \\
3 & Point & 476773.63 & 748462.06 & Atan-Ota \\
4 & Point & 501173.91 & 751053.5 & Olorunda \\
5 & Point & 492728.19 & 728213.75 & Ado-Odo \\
6 & Point & 482126.16 & 720187.63 & Ipokia \\
7 & Point & $514274 . .03$ & 721255.75 & Igbesa \\
8 & Point & 526160.69 & 740856.25 & Sango-ota \\
9 & Point & 521969.50 & 763054.75 & Ewekoro \\
10 & Point & 577456.43 & 786856.25 & Ajebo \\
11 & Point & 514769.40 & 749557.81 & Akinsinde \\
13 & Point & 514242.90 & 725196.93 & Lusada \\
14 & Point & 544035.93 & 759864.87 & Mokoloki \\
15 & Point & 534860.43 & 742414.37 & Ilepa \\
\hline
\end{tabular}

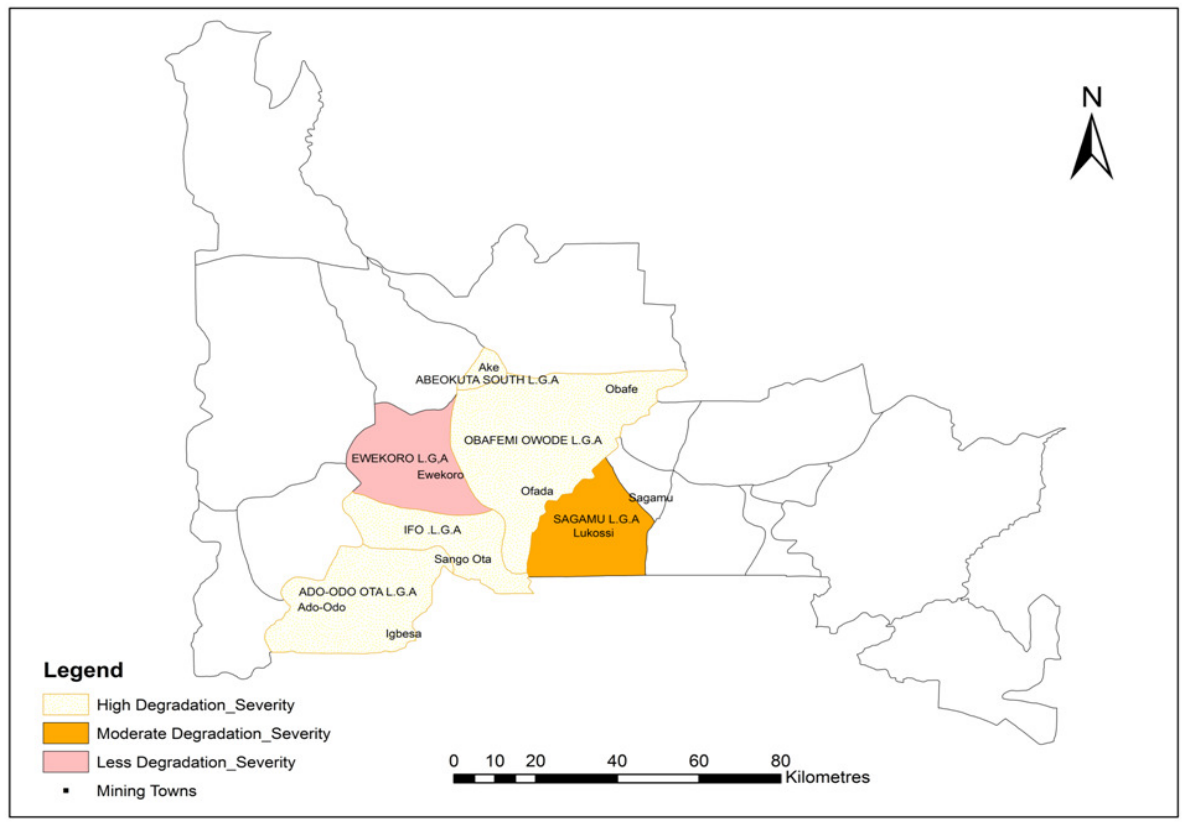

Figure 3: Severity of Impacts of Sand Mining Activities in Ogun State 
In fact, in most areas, unscientific and illegal sand mining operations have caused severe degradation of land, often accompanied by subsidence and severe ecological imbalance and damage to land use patterns in and around mining regions (Sear and Archer, 1998; Chauhan, 2010). Sand mining can represent a conflict with competing land uses such as farming, especially in areas where high-value farmland is scarce and where post-mining restoration may not be feasible. The most direct environmental impact of sand mining is the loss of agricultural land leading to soil erosion, land dereliction and ground water pollution (Peckenham et al., 2009). The reduction or loss of farmlands often causes confrontation between farmers and mining contractors (Ross, 2001). Since most sand miners do not preserve the topsoil removed before excavation begins, the topsoil is often washed away into surface water, carrying with it ecologically valuable seed banks that are necessary for the regeneration of vegetation. The sand mining activities scarified the different locations (Figure 4) which may not be easily restored.

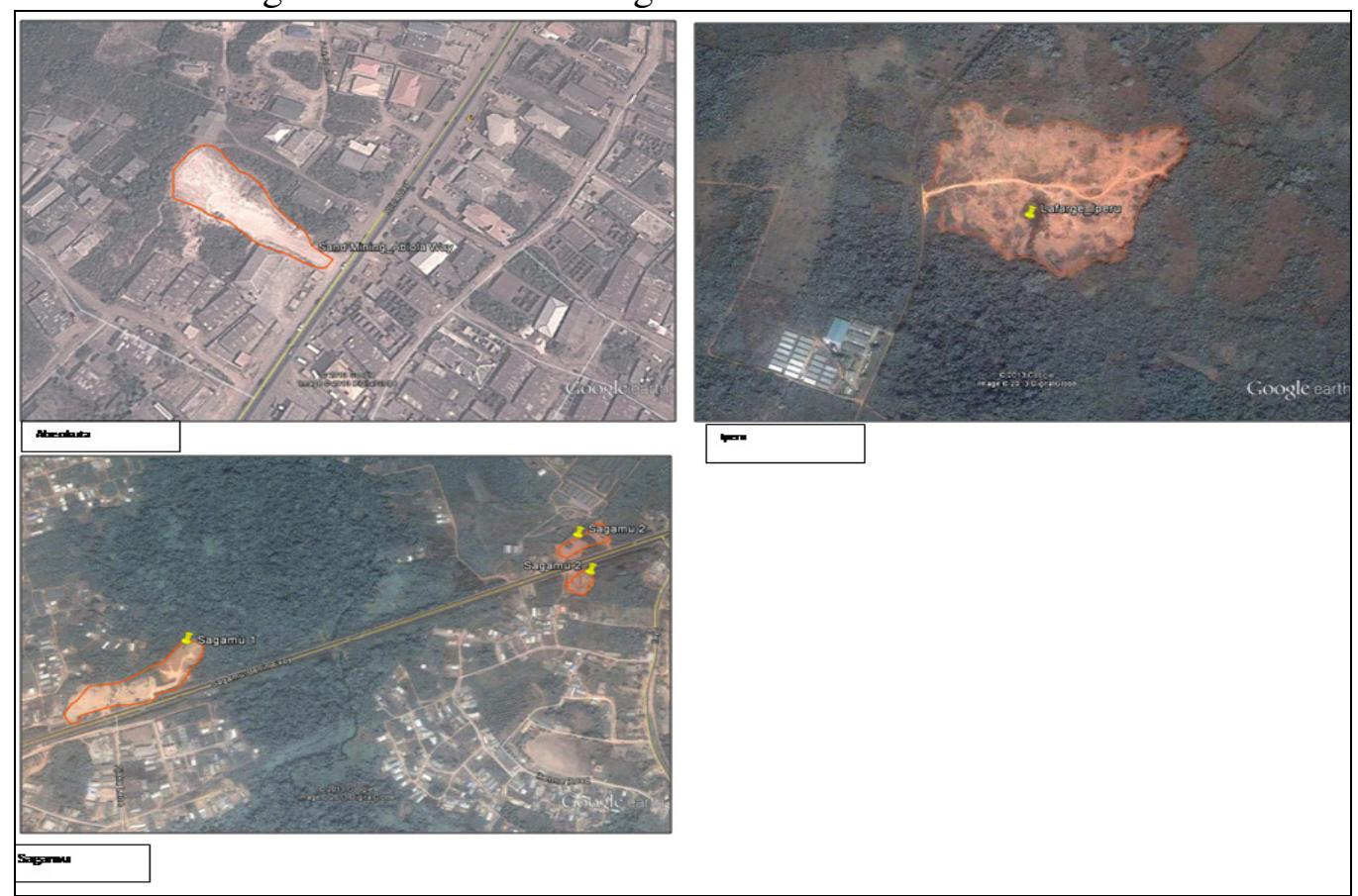

Figure 4: Scarification of Land by Sand Mining Activities in Abeokuta, Iperu and Sagamu Area of Ogun State

The indirect impacts include pollution, noise and odour arising from use of burrow pits as waste dumps. As there are presently no attempts by government agencies to control mining activities, miners excavate as deeply as they like usually until they expose the water table (Navaratne, 2009). This factor has turned most of the burrow pits into ponds (Welhan, 2001) which constitute nuisance to the people in the areas affected. When used for waste dumping, burrow pits, become the sites of noise and offensive odours. Final disposal of solid waste from the streets of Igbesa for instance is in form of open unsanitary dumps. Little or no sorting is done before final disposal with the only form of sorting done by human scavengers. Daily covering of these wastes, sealing of the bottom of these burrow pits and compaction are completely absent. In Lusada, one of the study communities, a waste dump in a disused sand mining site is just about five (5) 
kilometres from the Agbara water works. Solid waste is usually transported in open trucks that are usually over loaded and continue to spill over on to the streets as the trucks drive by causing more litter and odour. In addition, Sand mining is a direct and obvious cause of erosion, and affects the local wildlife. Sand mining is a source of air pollution and the main air quality issue with mining is dust particles (Ghose and Kumar 2004). Large amounts in concentrations of dust can be a health hazard, exacerbating respiratory disorders such as asthma and irritating the lungs and bronchial passages. However, people invariably feel a loss of environmental amenity, due to dust deposits or dust concentration, before their health is affected. The situation at Lukosi village near Abeokuta in the picture below indicated that as the air within the neighbourhood of the site is being polluted exposing people to carcinogenic diseases.

Sand mining activities can affect surface runoff and groundwater quality through contamination with dissolved and suspended materials (Hemalatha et al., 2005). Apart from runoff from overburden emplacements and stockpiles, storm water can be contaminated from process plants, workshops and vehicle wash-down pads. Mines can dewater groundwater aquifers some distance from shafts or open pits, which can make nearby wells or groundwater bores run dry. Sand mining often disturbs the landscape as the activities can result in the destruction of the existing vegetation and soil profile. Landscape destruction is a significant effect of mining because mining activities usually scar the landscape with excavated pits and trenches, leaving behind unsightly views, which as well render the land unsuitable for any productive purpose. Such destruction of land because of mining therefore changes the land surface. Mining pits can significantly change the topography and stability of the landscape. Clearing vegetation poses the most serious threat to biodiversity. Once land is cleared, it is impossible to restore the full suite of indigenous species, remove pest plants and animals, and repair ecological processes (Heath et al., 1993; Moody and Panos, 1997). Inland Sand mining is the major cause of deforestation and forest degradation, as commercially valuable minerals like sand are found in the ground beneath forests. Forest degradation due to mining projects has other effects: it causes a decline in the natural environment's productivity, and it renders the local community more vulnerable to fatal floods, landslides, adverse climatic shocks, and other natural disasters (Rhett, 2006). The trees along the Sagamu/Ore expressway in Sagamu are almost cut off all in the name of mining of sand. From the picture below, it is evident that productive flora and fauna is slowly being destroyed by these indirect deforestation activities, which also form vast tracts of a very valuable sink for carbon dioxide. Flooding can also be attributed to sand mining activities in parts of the state. Flooding often damages public infrastructure such as bridges, roads, schools and water supply systems. Furthermore, flooding results in the loss of crops, farms and livestock. The abandoned pit serves as a source of breeding grounds for mosquitoes for example, and the resultant spread of malaria and other related diseases were evident of Mokoloki and Igbesa because of the nature of the environment and because of confirmation by the people in the community. During rainy seasons, the abandoned pits collect water and as a result attract malaria parasites resulting in infection of community people. Other diseases such as cholera, dysentery and diarrhoea, among others, are associated with the mining activities, since abandon pits serves as solid waste dumping sites.

\section{Destruction of Infrastructures}

Apart from the environmental damages, infrastructural facilities such as roads, water, 
electricity and others destroyed by the activities of these illegal sand miners. In this study, many communities are seriously affected for instance in Lusada area of AdoOdo/Ota local government area. Infrastructures such as electricity poles are serious breached which makes them to lean dangerously and can be disastrous if eventually the pole falls (Figure 5). In Sagamu, the base of the electricity substation had being evacuated exposing the whole area to severe erosion and an impending disaster. Many of the pylons carrying high-tension wire have had the sand at their based almost removed. The situation is terrible at Ado-Odo as completed buildings are almost collapsing. This study has shown that the communities pay the greater environmental price due to the sand mining activities. Inland sand mining generates extra vehicle traffic, which negatively impairs the environment. Where access road crosses riparian areas, the local environment may be impacted upon. It was observed that owners of mines are mostly from outside the locations where the mining were taking place. They are regarded in local parlance as "non-indigenes" and are all males while the women are only involved in selling the product. The oldest active inland sand mining site started operation in 1975 when the land was bought by the miners from the original owners. Miners do not operate in unions but those who sell the products have unions to protect their activities. On payment of tax and levies to government, the local government issues an annual work permit to owners of mines with a payment of a fee of N36,000 (approximately \$225 USA). Twelve (12) operators said they were unaware of provisions of the Land Use Act or the Ogun State Law for Physical Development for their operations. Miners expressed the view that while they recognized the impact of their activities, they could not see the need for control measures since the land was private property (Anderson, 1997). Interestingly, eight (8) of the active site operators indicated their intention to re-use the land for other economic purposes when excavation stops.

GIS and remote sensing techniques have proved to be veritable tools in locating sand mining sites especially in remote areas. The techniques play important roles in monitoring and assessing the extent of damage to the environment by sand mining activities. GIS can be used to map severity of sand mining activities and plan restoration of degraded land resources. The GIS analytical techniques such as overlays of different vector layer using software such as ArcGIS 9.3 help to produce maps that are The results of GIS analysis are important in decision making for managing use of land, resources or any other spatially distributed entities. Locating and collecting geospatial information on sand mining using GIS fast track quick decision-making and forestall further degradation.

\section{Conclusion}

This study has identified the locations of inland sand mining activities in Ogun State using GIS. It was found out that inland sand mining is common in most parts of the state. However, it is more intense in Sagamu, AdoOdo/Ota, Ifo and Abeokuta South local government areas owning to the rapid urbanisation around these areas. These have resulted in high level of environmental degradation in many parts of the state. There is need to create awareness in this regard. Communities need awareness on how best to manage their land resources in order to protect the land assets from depreciation and degradation. Environmental indicators need to be put in place so that the set standards and regulations are enforced through monitoring and inspection. A synergy between various relevant institutions dealing with natural resources should be established. This can be in the form of coordinating training, 
awareness, monitoring and regulating programmes. Finally, an integrated environmental assessment, management, and monitoring programme should be a part of any sand extraction operation, and encouraged at national, regional, district, and local levels. Assessment is used to predict possible environmental impacts and encourage public participation at the decision level, whilst management is used to implement plans to prevent or minimize negative impacts.

\section{References}

Abdus-Saleque, K. (2008). Social and Environmental Impacts of MiningAustralian Lessons on Mitigation.

Akabzaa, T.M. (2000). Boom and Dislocation: The environmental and social impacts of mining in the Wassa West District of Ghana. Accra: Third World Network - Africa.

Akabzaa, T. and Darimani, A. (2001). Impact of Mining Sector Investment in Ghana: A study of the Tarkwa Mining region.

Anderson, K. (1997). Analyzing and Mitigating Social Impacts of mining. A Paper presented at the Asian/Pacific Workshop on Managing the Social Impacts of Mining Bandung, Indonesia, 14-15 October 1996.

Burrough, P. and McDonnell, O. (2002). Remote Sensing and GIS, Oxford University Press, UK $445-447$.

Chandra, A.M. and Ghosh, S.K. (2009). Remote Sensing and Geographical Information System. Narosa Publishing house, New Delhi, 345

Chauhan, S. S. (2010). Mining, Development and Environment: A Case Study of Bijolia Mining Area in Rajasthan, India. J Hum Ecol, 31(1): 65-72.

Chindo, M. (2011). An Extensive Analysis of Mining in Nigeria Using a GIS. Journal of Geography and Geology 3(1): 3-12 doi:10.5539/jgg.v3n1p3
Davis, G. and Tilton, J. (2005). The resource curse. Natural Resources Forum, vol. 29, p.233- 242

Erskine, W.D. and Green, D. (2000). Geomorphic effects of extractive industries and their implications for river management: the case of the Hawkesbury-Nepean River, New South Wales. In Brizga, S. \& Finlayson. B. (Eds.), River Management: The Australian Experience (pp 123149). Chichester, UK: Wiley.

ESRI (Earth Systems Research Institute). (2010). What is GIS? Overview. [Online] Available at:http://www.esri.com/what-isgis/index.html (April 20, 2010).

Ezekiel, E. (2010). Nigeria needs N45 trillion to tackle housing deficit-FMBN. Nigerian Business Forum, 18 Nov.

Ghose, M.K. and Kumar, A. (2004). Mineral industries and their environmental aspects in Indian context. Indian Journal of Engineering \& Materials Sciences. Vol. 11, October, pp. 433437.

Gob, F., Houbrechts, G., Hiver, J.M. and Petit, F. (2005). River dredging, channel dynamics and bedload transport in an incised meandering channel (The River Semois Belgium), River Research and Applications, 21, 791-804.

Heath, M.J., Merefield, J.R. and Paithankar, A.G. (1993). Environmental impact of mining on tropical forest. Mining Environmental Management, 37, 1416.

Hemalatha, A.C., Chandrakanth, M.G. and Nagaraj, N. (2005). Effect of sand mining on groundwater depletion in Karnataka; In: International R\&D Conference of the central board of irrigation and power, Bangalore, 15-18 February 2005.

Heywood, I., Cornelius, S., and Carver, S. (2006). An Introduction to 
Assessing Environmental Impacts Of Inland Sand Mining................ADEDEJI et al.

Geographical Information

Systems.3rd Edition, Pearson Education

Limited, Edinburgh Gate

England, 435

Huntington, H.P. (2000). Using traditional ecological knowledge in science: Methods and applications. Ecological Applications, 10, 1270-1274.

Isah, R. (2011). Nigeria: Making housing fund contribution national agenda. [Online] Available at: http://allafrica.com/stories/201106240782.h tml (June 30, 2011).

Jiriko, K.G. (1995). Physical Planning and exploration/exploitation of Cassiterite on the Jos Plateau. Proceedings of the 26th Annual Conference of the Nigeria Institute of Town Planners, NITP, Lagos, 10-25.

Kadi, A.S., Halingali, B.I. and Ravishankar, P. (2012). Problems of Urbanization in Developing Countries: A Case Study in India.

Kondolf, G.M. (1994). Geomorphic and environmental effects of in stream gravel mining, Landscape and Urban Planning, 28: 225-243.

Makweba, M.M. and Ndonde, P.B. (1996). The mineral sector and the national environmental policy. In: M.J. Mwandosya et al (Eds.), Proceedings of the workshop on the national environmental policy for Tanzania (Dar es Salaam, Tanzania), 1994; 1996. (pp 164- 173).

Moody, R. and Panos, S.P. (1997). Environmental assessment of mining projects. Available at: http://www.worldbank.org/mining.xls (Accessed on 22 July, 2012)

Navaratne, C. (2009). Negative impacts of unregulated, illegal river sand mining on livelihood, human well being, domestic water supply sectors and agriculture; NetWater, presentation at 5th World Water Forum, Istanbul, Turkey.
Omole, D and Ajakaiye, O. (1998). Environmental Externalities and Sustainable Urban development: who bears environmental costs, In: Adeniji, K. and Ogu, V.I. (Eds), Sustainable physical development in Nigeria, Ibadan: Nigerian Institute of Social and Economic Research, 115-132?

Peckenham, J.M., Thornton, T. and Whalen, B. (2009). Sand and gravel mining: effects on ground water resources in Hancock County, Maine, USA. Environmental Geology 56, 1103-1114.

Rhett, B. A. (2006). Environmental impact of mining in the rainforest. Mongabay.com/ Place Out of Time: Tropical Rainforests and the Perils They Face.

Ross, M. (2001). Extractive resources and the poor. Boston: Oxfam America Report.

Sayami, M. and Tamrakar, N.K. (2007). Status of sand mining and quality in northern Kathmandu, Central Nepal; in: Bulletin of the Department of Geology, 10: 89-98.

Schleupner, C. and Schneider, U.A. (2012). GIS-Based Estimation of Wetland Conservation Potentials in Europe. Applied Ecology and Environmental Research 10(4): 385-403. http://www.ecology.uni-corvinus.hu

Welhan, J. (2001). Ground-water interactions near the highway pond gravel pit, Pocatello, Idaho. Staff Report 01-3. Moscow: Idaho Geological Survey.

Willis, K.G. and Garrod, D. (1999). Externalities from extraction of aggregates regulation by tax or landuse controls. Resources Policy, 25, 77153.

World Rainforest Movement (2004), Mining: "Social and Environmental Impacts". 